\title{
North Korean Refugees in South Korea: Change and Challenge in Settlement Support Policy
}

\author{
Gyubin Choi
}

The aim of this article is to examine the structural conditions that affect the problem of North Korean refugees in South Korea. It provides a historical review of the changing perception and policy toward the Democratic People's Republic of Korea (DPRK), or North Korea, and how these changes and broader inter-Korean relations have affected the identities of North Korean refugees and the way of they have been dealt with. Understanding the evolution of South Korea's policy toward North Korea and North Korean refugees is important because the policy is the output of the perceptions of political elites of the North Korean regime itself and North Koreans refugees in South Korea, and it involves decisions regarding who they are, why and to what extent should the state offer protection to them, and how to implement such policies. These political conditions constructed by the state and system of states directly and indirectly cause many of the difficulties, confusions, and problems facing North Korean refugees. In this sense, this paper argues that the causes, consequences, and responses to North Korean refugees are a part of much broader political, as well as humanitarian, issues. The paper focuses primarily on these factors affecting South Korea's policy toward North Korean refugees and resultant changes in the status and treatment of those refugees in the Republic of Korea, or South Korea. This paper then explores the challenges that North Korean refugees face in the process of adjusting to South Korean society.

Key Words: North Korean refugees, defectors, settlement support policy, inter-Korean relations

\footnotetext{
*Gyubin Choi(gbchoi@snu.ac.kr) is a senior researcher at the Institute for Peace and Unification Studies (IPUS) at Seoul National University. His research interests focus on inter-Korean relations, South Korea's engagement policy toward North Korea, the politics of humanitarian assistance, and the broader international relations of the Asia-Pacific. He recently published "Comparative Analysis of North and South Korean Perceptions toward Neighboring Countries" (Unification and Peace, 2016).
} 


\section{NORTH KOREAN REFUGEES AS INTERNATIONAL AND DOMECTIC POLITICS}

\section{DUAL NATURE OF THE REFUGEE ISSUE}

The 'problem' of North Korean refugees stems not only from its humanitarian nature but also from its political nature of human displacement. Refugees are a humanitarian issue in the sense that they are people who left their home countries due to a variety of domestic political and economic factors, and so are people in need of international protection and assistance. They normally seek asylum in other states, and these asylum-seekers generally want to be recognized as refugee by the host state. Although these displaced peoples have various reasons to leave their homes, not all who cross an international border can be considered refugees. According to the international legal definition enshrined in the 1951 UN Refugee Convention, ${ }^{1}$ together with the 1967 Protocol, $^{2}$ a refugee is someone who leaves his or her country of origin as a result of a well-founded fear of persecution for reasons of race, religion, nationality, membership of a particular social group, or harbouring political opinions in opposition to the regime (UNHCR 2010, 14). The nature of the Refugee Convention's requirement of persecution may exclude other types of displaced peoples who have fled due to environmental disasters, economic hardships such as famine or abject poverty, and political events such as internal domestic conflicts or endemic or systematic violence (Barnett 2014, 247; Goodwin-Gill 2014, 41). Because of the 'softness' of the definition, identifying and understanding the refugee 'problem' requires normative considerations of who they are and why they leave.

Regardless of how it is defined, the refugee phenomenon involves multiple histories and political issues linked to security, peace, and the responsibility of the state to its people, and international society to its global citizens (Betts and Loescher 2011). This means that the refugee problem can be attributed to the state-centric nature of the international system based on supremacy of the sovereignty of individual states. While it is true that international community, particularly the Office of the United Nations High Commissioner for Refugees (UNHCR), plays an important role improving awareness of the plight and rights of refugees, and of promoting the implementation of refugee norms, it is particular states that deal with refugees and displaced peoples of all kinds

\footnotetext{
${ }^{1}$ Convention relating to the Status of Refugees, Accessed at http://www.ohchr.org/Documents/ ProfessionalInterest/refugees.pdf (October 11, 2017).

${ }^{2}$ Protocol relating to the Status of Refugees, Accessed at http://www.ohchr.org/Documents/ ProfessionalInterest/protocolrefugees.pdf (October 1, 2017).
} 
who are forced to flee across an international border (Loescher 2001). To put it another way, refugee status is determined by the state, in contrast to asylum seekers, and that refugee designation is granted to individuals not groups. As a consequence, the acceptance of select individual as refugees and the provision of protections to those individuals are enacted by domestic law and predicated on that state's own national sovereignty.

One state's failure to protect its own people is connected to another state's actions of accommodating them or regulating their inflow, which may be sources of instability. A state's decision is made based on the complex considerations of each state's national interests, security threats, domestic legal systems, and the overarching international norms or rules that shape international society. As Maley $(2016,41)$ argued, refugee issues lie "between domestic politics and international relations," and they concern issues of both individual state sovereignty and responsibility. In this sense, the refugee problem stems from the inherent tension between international responsibility to protect refugees and a range of vulnerable people, and the state's sovereign authority to regulate forced migration. The case of North Korean refugees exemplifies this dilemma as well.

\section{NORTH KOREAN REFUGEES AS THE POLITICAL AGENDA}

The emergence, movement, and treatment of North Korean refugees are intrinsically political. Firstly, the origin of refugees in Korea had to do with the political structure of the Korean peninsula. The division of Korea made a physical border that divided one ethnically homogeneous people and caused early 'war-refugee' movements between the mid-1940s and the early 1950s. The practical border, the $38^{\text {th }}$ parallel between the two Koreas, plays a role in separating the two states and preventing the free movement of people between the two. Kim $(2000,121)$ argued that at the time fleeing from the North's communism was regarded as an important "sign" or "qualification" to settle down in South Korea, describing Korean society during the Korean War as a "refuge society." In South Korea, these so-called "War Refugees" (pinanmin) became recognized as "People Who Lost Their Hometown" (silhyangmin) or "Separated Families" (isangajok) (Chung 2009, 7). In this regard, the division of Korea including the establishment of separate governments, and the outbreak of the Korean War had much to do with the origin of refugees in Korea. Most became refugees because of the Korean War, and the resultant intense crossborder movement of people occurred during the war period.

Secondly, since the end of the Cold War, the increase in North Korean refugees has resulted from the state's failure to protect its populations and its incapacity to respond to political and economic crises in North Korea. Along with 
devastating natural disasters such as droughts and floods throughout the 1990s, severe food shortages also made a difficult situation worse. The inefficiency and limitations of the ruling elite's power to deal with economic crises drove North Korean citizens to find their own ways to survive (Won 2003, 199). As a result, displaced North Koreans remarkably have spread throughout East Asia since the mid-1990s, receiving more attention from the international community. These North Koreans, regardless of whether they are recognized as refugees or (non-)citizens by the receiving states, show the features of the diaspora and the patterns of transnational networks (Yoon 2001; Park et al. 2011).

Thirdly, from the perspective of responses, states play a key role in determining who is a refugee and what responsibilities and institutional obligations do states have to those displaced North Koreans. When North Korean refugees come to South Korea, they go through a procedure at a protection center where government agencies, including the National Intelligence Service (NIS), conduct interrogations by questioning them about their motivations for leaving and other aspects of their backgrounds. Thereafter, they are assigned to the Settlement Support Center for North Korean Refugees, known as a 'Hanawon,' where North Korean refugees attend a social orientation program and receive an adjustment education. In this sense, the government plays a key role in providing protections, legal membership, assistance, and social education. Leaving their homeland due to fear of persecution, as well as due to other environmental, economic, or political reasons, is an issue in the domain of individual rights as a human being. However, the management of refugee flows, judgment of refugee status, and provision of relief are within the purview of state sovereignty.

North Korean refugees have a unique feature in that they can be entitled to different identities among citizens, refugees, and migrants, contingent on where they are temporarily or permanently located (Song 2016). For instance, China and South Korea have different perceptions about, and policies toward, North Korean refugees. Whereas China does not accept North Korean escapees as refugees, regarding North Koreans in Chinese territory as illegal migrant workers or economic migrants, South Korea seeks to accommodate all who flee the North and so grants citizenship to North Koreans entering South Korea. The perspective of the Chinese government means that the principle of refoulement is to be applied to all North Koreans who have moved into China, ${ }^{3}$ and as the act of sovereignty, forced repatriation of those 'workers' is necessary to "maintaining national security, social order and border controls" (Cohen 2014, 69). China's

\footnotetext{
${ }^{3}$ The Chinese government restrictively allowed North Koreans who managed to enter foreign embassies and consulates to depart for countries in which they want to settle down.
} 
reactions of forcible repatriations also were based on its legal agreements with North Korea in 1962 and in 1986 (Shen and Xia 2013, 2014; Cohen 2014; KINU 2005).

By contrast, the position of the South Korean government is that North Koreans are citizens the South Korean government should protect. It is based on the South Korean Constitution, which defines South Korean boundaries as the Korean peninsula and its adjacent islands (Article 3). The 1997 Act on the Protection and Settlement Support of Residents Escaping from North also stipulates that the principle of citizenship and protection applies to people "escaping from the area north of the Military Demarcation Line," who seek protection from South Korea (Article 1). Accordingly, it is a legal obligation for South Korea to claim diplomatic protection, to provide settlement support, and to grant citizenship to those who have fled to the South.

The position whether overseas North Koreans should be recognized as refugees or general migrants also varies among signatories of the 1951 Convention Relating to the Status of Refugees. The former means that some countries accept North Koreans as refugees. The UNHCR estimates that the number of North Koreans who have been granted refugee status around the globe was 1,422 in 2016 (UNHCR 2016). The latter implies that overseas North Korean defectors are 'voluntary' migrants who leave mainly to rebuild their lives. They choose to move abroad for economic and other reasons, and migrate to "the best places to live" for better economic opportunities (Song 2015, 399). Considering the motivations and movements of North Koreans, they are not victims or asylum seekers who must demonstrate their persecution or suffering in order to obtain legal status, but rather are considered autonomous migrants taking advantage of globalization.

Once they are designated as refugees or granted citizenship by each receiving state, resettlement and reintegration of refugees become an important part of the political and societal agendas that individual states have to deal with. This reality shows that modern state sovereignty affects the status and treatment of North Korean refugees. As Haddad (2009) points out, a state is both a creator

\footnotetext{
${ }^{4}$ When the Boundary Treaty between China and North Korea was signed in 1962, illegal border crossings were one of the main issues between the two states (Shen and Xia 2013). Although there was the initial Sino-North Korea agreement on border-crossings in 1955 that required forced repatriations of migrants who illegally stayed in the other's country, but it was not strictly regulated. At the time, cross-border migrations between China and North Korea mainly took place by those North Korean residents in China (ethnic Koreans of Chinese nationality) who moved to North Korea (Shen and Xia 2014; Lankov 2004). The two sides later made a stronger agreement on the management of border controls in 1986 (Cohen 2014; 2010; Lee et al. 2012).
} 
of and problem-solver for refugees. Given the role of the state in refugee issues and the inherent political nature of the refugee concept, the question becomes how the political environment affects the different perceptions, institutional priorities, and government policies toward North Korean defectors.

\section{CHANGES IN INTER-KOREAN RELATIONS AND SETTLEMENT SUPPORT FOR NORTH KOREANS}

The policy of the South Korean government toward North Korean refugees has changed markedly over the past several decades. Although the process and plight of North Korean refugees have been discussed extensively, there has been a shortage of work on what structural factors have shaped these changes. Naturally, there are various ideological perspectives toward North Korea, as well as a host of societal and humanitarian views of escaped North Koreans among South Korean policymakers and practitioners. Nevertheless, the issue of North Korean refugees is political in that the state's failure in North Korea has caused this exodus, and this phenomenon is inseparable from national division and the continuing conflict between the two Koreas. For these reasons, it is useful to explore the political changes that have taken place in inter-Korean relations and the policy practices towards North Korean refugees in South Korea.

THE COLD WAR AND REGIME COMPETITION (1962-1993)

While a few North Koreans were able to come to the South between the mid1950 and the end of decade, they were treated as special cases. It was during the Park Chung-hee era that South Korea adopted a specific law to regulate the status of North Korean border crossers and the boundaries of government support. The Park government enforced the 'Special Relief Act for Patriots and Heroes Who Returned to the State' (gukgayugongja mit wolnamgwisunja teukbyeolwonhobeop) in April 1962. With this act, the South Korean government institutionalized support for North Korean defectors for the first time. Although the number of North Korean defectors was low, the law paved the way for providing them with special treatment and financial assistance. At the time, the South Korean government described North Koreans who fled to South Korea as 'gwisunja,' literally meaning a person who used to be an enemy but who abandoned an attitude of defiance while voluntarily pledging obedience to the new state. Thus, the use of the term 'gwisunja' implied that the refugees came from an enemy state (Heller 2011). This act incorporated the treatment of North Korean defectors into broader applications of rights and services to patriots 
of the independence movement and the victims of the April 19th revolution. It meant that the government treated them the same as persons of distinguished service to South Korea (Chung 2004). The government revised the law later, integrating the related regulations of North Korean defectors into the 'Special Compensation Act for Heroes' (wolnamgwisunyongsa teukbyeolbosangbeop) in January 1979. This act allowed for North Korean defectors who adopted liberal democracy in the South while abandoning communism in the North to be treated in a special way as 'Heroes Who Returned to the State' (wolnamgwisunyongsa).

From a political point of view, these defectors were vital to the South Korean government in that they had political propaganda value, as well as military and political information about North Korea (Choi 2011). Accordingly, generous support followed. The government provided settlement benefits (from KRW 19 million), employment incentives, the provision of free housing (more 50 square meters), job placement for family members, education subsidies, and medical treatment. These 'special' benefits increased for those who had military secrets to share about North Korea. In fact, the department taking charge of these protections and support for North Korean defectors was the Ministry of Defense. Chung $(2009,8)$ has pointed out that, for the South Korean government, defectors who gave valuable information about the North to the South were "excellent propaganda tools to prove the superiority of the South Korean capitalist system." This suggests that determinations of the status and level of support for North Korean defectors were made not only in reflection of a sense of nationalism or moral responsibility, but also to serve various political interests and strategic purposes.

The politicization of North Korean defectors between the early 1960 s and the end of the 1980 s can be attributed to policy elite perceptions of the North Korean threat, the regime's interest in emphasizing security, and the legitimization of the military government.

First, the South Korean leadership's interpretation of North Korean threat would continue to have a decisive influence on the political agenda and mode of interactions between the government and the North Korean defectors. Park believed that the danger of a North Korean attack was real, and South Korea's military strength was less formidable compared to North Korea's (Memorandum of Conversation 35 1969). The nature of the discourse of the ruling elites of South Korean about the North Korean threat played an important role in causing the connection of the issue of North Korean defections with the government's political interests. This feature was salient in the Park regime during the 1970s.

Second, the Park government's urgent goal of winning the nation-building competition with Pyongyang shaped the motivations for various policies. To be 
certain, both North and South Korea engaged in a fierce competition for their own survival and prosperity. Whereas Pyongyang pursued its own economic plans and mass mobilization campaigns such as the 'Chollima Movement' in the late 1960s, Seoul had a vision to transform South Korea into an economically prosperous and militarily strong state (bugukgangbyeong). By the late 1960s, it was generally believed that South Korea had fallen behind North Korea (Yang 2008; Eberstadt 2007). From a legal perspective, North Korea has never been officially recognized as a nation despite the existence of the government. In this sense, the treatment of North Korean defectors is strongly associated with the South's sense of insecurity and perceived antagonism toward North Korea.

Third, the special treatment of North Korean defectors as 'heroes' and South Korean elites' tough stance against the North served to stir up anti-communism and nationalist sentiments in the South. For instance, at the 1983 Naval Academy graduation ceremony President Chun Doo-hwan stated, "a heroic attempt of North Korean pilot Lee Ung-pyong who flew to South Korea with the MIG jet fighter was a good sign to prove our victory in inter-Korean regime competition" (Chun 1984). The nature of the challenges facing South Korean policymakers did not shift in the 1980s. Military deterrence and economic development were still the primary goals of the Chun Doo-hwan government. Although there has been an effort to make progress in inter-Korean relations an integral part of foreign and unification policies, the government's basic stance towards North Korea of direct competition and hostility has not changed. Chun used anti-communist rhetoric and stressed the North Korean threat as a means of legitimizing his rule. Namely, the nation's vital interest in the task of modernization, coupled with policymakers' interpretation of the North Korean threat, played a major role in shaping the regime's actions, policies and strategies.

THE POST-COLD WAR AND INTER-KOREAN COEXISTENCE (1993-1997) The period of the 1990 s is important for North Korean refugees. Faced with a serious food crisis precipitated by chronic economic crises and natural disasters in North Korea, a large-scale border movement occurred at the SinoKorean border and beyond in the mid-1990s (Smith 2005; Lankov 2004). As a consequence, the number of North Korean refugees increased dramatically in the 1990s. Whereas only 59 North Korean defectors arrived in South Korea in the 1970 s and 63 in the 1980s, the number rose to 488 in the 1990s. Of those, 243 North Korean defectors came to South Korea between 1993 and 1997. A growing numbers of North Korean refugees also meant that the government's financial burden to support them continued to increase. 
Quantitative changes in North Korean refugees also involve manifold features of defector movements. The backgrounds of North Koreans defectors had changed. Until the early 1990s, most of them were North Korean elites, such as former diplomats, businessmen, and government officials, and the underlying motives and intentions driving North Korean elites to leave the country were mainly related to political reasons. However, the composition of North Korean defectors varied over time, showing a change to more 'economic refugees.' Those North Koreans who previously had been workers, farmers, housewives, low-ranking soldiers, and students often lacked the capacity for economic activities (Yoon 2003). Indeed, due to the lack of job opportunities and work competencies, many North Korean settlers in South Korea were more likely to be vulnerable in South Korean society. The adjustment of North Korean refugees to the new environment became a critical part of the political agenda in South Korea.

The policy towards North Korean defectors was changed with the 'Act to Protect North Korean Brethren Who Returned to the State' (gwisunbukhandongpo bohobeop), legislated in December 1993. Although this law retained the phrase 'Who Returned to the State' (gwisunja), it added 'compatriots' (dongpo), connoting the meaning of an ethnic Korean. Under this new act, the main policy objectives shifted from granting generous benefits in line with patriots to providing protection and practical assistance to those who lacked the independent capacity for daily living under social welfare (Lee 1999). The approach of the South Korean government showed that North Korean refugees were not perceived as heroes or brave defectors anymore, but rather were considered deprived compatriots who might lack the capacity for independent living, much like other welfare recipients (Kwon 2014, 110). Reflecting this reality, the office primarily responsible for North Korean refugees was changed from the Ministry of Defense to the Ministry to Health and Welfare.

Accordingly, the amount of the initial settlement benefits allocated to a single family markedly decreased to KRW 6.9 million (about US\$7,000), and additional benefits were granted proportionally in consideration of the size of household, health conditions, and the ability to work (Jung et al. 2010). In terms of housing support, the government paid the key money (deposit) for rentals, no longer just providing a free apartment. Compared to the previous period regulated by the 1979 Special Compensation Act for Heroes, the scale and volume of material support in the mid-1990s was substantially reduced by the 1993 act. However, this policy direction turned out to be ineffective in its ability to assist North Korean defectors in many ways because it precipitated poverty and unemployment among members of the refugee community (Park 2002). 
This maladjustment caused the South Korean government to again revise its policy, enacting a new law in 1997.

It should be pointed out that the government's change of attitude towards North Korean refugees and government policy were associated with not only Seoul's domestic conditions and the government's attitudes towards North Korea, but also large-scale changes took place in the international system that led to the end of the Cold War. This is significant because political relations between North and South Korea broke new ground under the administrations of Roh Tae-woo and Kim Young-sam in the mid- to late-1990s.

Indeed, both the Roh and Kim administrations reasoned that it was not possible, nor desirable, to bring down the North Korean regime from the outside. Faced with the collapse of the communist governments of east European countries of the Soviet bloc, the disintegration of the Soviet Union, and the unification of East and West Germany, there was an initial expectation that the North would follow the Chinese model and undertake a process of gradual opening and economic reform. However, even at that time, the Roh government's policy goals were not aimed at achieving unification through absorption, the demise of communism in North Korea, or the radical reform of the Kim Il-sung regime. South Korea was in a more advantageous position than North Korea, being under less pressure from inter-Korean regime competition. As South Korea's national power surpassed North Korea's, the political need to use North Korean defectors as propaganda tools steadily diminished. On the contrary, with the end of the Cold War and the growing economic strength of South Korea, North Korea faced domestic economic turmoil and external security threats. In essence, diplomatic recognition of South Korea by China and the Soviet Union sent shockwaves through North Korea, both politically- and ideologically-motivated (Yeon 1986; Koo and Jo 1995).

Changes in the international arena between the late 1980 s and the early 1990 s encouraged the influx of North Korean defectors. Kim (1994) argued that as North Koreans obtained more information about the economic development of South Korea and got to know about diplomatic normalization and the improvement of the relationship between China and South Korea, this environment became an important factor in leading to greater numbers of refugees. The impact of the geopolitical changes in the post-Cold War era presented a more substantial threat to North Korea. Pyongyang encountered a serious decline in capital and material support from both the Soviet Union and China between the late 1980s and the early 1990s. As a result, the disruptions in trade with the Soviet Union and China had a greater effect on the North Korean economic system, aggravating their economic hardship (Cha 2012; Ko et al. 2004). 
Namely, the rapidly changing international security order after Cold War and Seoul's confidence about the disparity in economic power between the two Koreas shaped the creation of a new international, political, and social environment around how to respond to North Korean refugees.

\section{THE SUNSHINE AND POST-SUNSHINE POLICY ERA (1997-present)}

At the end of his term in office, South Korean President Kim Young-sam revised the 1993 act, implementing the 'Act on the Protection and Settlement Support of the Residents Escaping from North Korea' (bukhanitaljuminui boho mit jeongchakjiwone gwanhan beopryul) in January 1997. It established a council for North Korean settlers, facility protection for one year, recognition of educational background and certificates earned in North Korea, the arrangement for social adaptation education, job training, and protection at the place of domicile for two years (Lee 1999). The managing authority was also changed from the Ministry of Health and Welfare to the Ministry of Unification. The Kim Daejung government amended the 1997 act, supplementing it with an enforcement ordinance in October 1998. It is noteworthy that the term 'Brethren Who Returned to the State' (gwisundongpo) was omitted from the law; instead being replaced by 'Residents Escaping from North Korea' (bukhanitaljumin). This, along with the rapidly increasing number of North Korean defectors, reflected the South Korean government's consideration of North Korean arrivals as entitled to social integration assistance, thereby linking policy to the larger goal of preparing for unification of the two Koreas. The Kim administration made it clear that "the settlement of the issue of defectors from North Korea would be the touchstone that shows the government's will and capability for unification of Korea" (MOU 2001, 157).

At the time, it was critical for the government to cope with the sharp increase in the number of North Korean defectors who entered South Korea or stayed in China, primarily because of North Korea's severe food shortages (Lee 2009). In 1999, the aggregate number of North Korean refugees exceeded 1,000 for the first time, and an additional 1,043 North Koreans entered South Korea from 1999-2001. Beyond protection and provision of material benefits, the South Korean government's agenda included post-settlement issues, socio-cultural adjustment, and economic self-reliance. The amount of the resettlement money for each person increased to KRW 27.6 million (approximately US\$27,000), rising four times over a period of five years. The standard size of rental housing was expanded from 50 ( 15 pyeong) to 85 square meters (25.7 pyeong). Additional subsidies were granted to vulnerable groups, and the amount of vocational training subsidies also increased from KRW 350,000 (about US\$350) 
to KRW 510,000 (about US\$510) a month. In particular, by establishing the resettlement support facility Hanawon in July 1999, the government was able to build an institutional framework for running social orientation programs for North Korean refugees. It was during the Kim Dae-jung regime that the present settlement support process consisting of entry and protection, the initial settlement support at Hanawon, and the post-settlement management at the municipal and provincial areas was built up in three stages.

A more systematic and institutionalized mechanism for North Korean refugees was in line with the interests of the more progressive administrations of Kim Dae-jung and Roh Moo-hyun in pursuing reconciliation and cooperation with North Korea. With the inception of Kim Dae-jung's Sunshine Policy, inter-Korean relations entered a new phase, and the government adopted an engagement approach to North Korea with the aim of fostering more cooperative political relations and positive changes in North Korea's behaviour (Moon 2000). The Sunshine Policy was based on a line of reasoning predicated on the belief that North Korea would not collapse immediately, and so a functional approach through the expansion of exchanges and economic interactions and deepening of interdependence was desirable for achieving the long-term goal of peaceful reunification (Kim 2004a). A central plank of Kim's Sunshine Policy was maintained by his successor, Roh Moo-hyun. The Kim and Roh administrations basically regarded the North as a dialogue partner, not a hostile enemy, viewing inter-Korean relations as being shaped by a 'unification-oriented special relationship' (Kim 2004b).

The political environment facing South Korean policymakers created a new space for laws and policies concerning North Korean refugees. It is worth noting that the South Korean government abandoned the term 'Who Returned to the State' (gwisunja) and adopted the term 'Residents Escaping from North Korea' (bukhanitaljumin). This change implied that South Korea was trying to break with the legacy of Cold War confrontation by changing the language used with respect to North Korean defectors. Nevertheless, the issue of what political discourse to use to identify or label North Koreans resettling in South Korea continues to be controversial (Kim 2012; Son 2016). Recognizing the negative connotation of the term 'North Korean Escapees' (talbukja), the government started using the non-political term 'New Settlers' (saeteomin) in 2005, expressing of North Koreans as 'persons with new homes who live in hope.' However, faced with criticism raised by North Korean refugees, who argued that this attenuated the political reasons for their fleeing the North, the Lee Myoungbak administration decided not to use this term; instead switching back to using the legal term 'Residents Escaping from North Korea' (bukhanitaljumin) in 2008. 
During his term in office, Lee revised the 'Act on the Protection and Settlement Support of Residents Escaped from North Korea' in 2009, emphasizing reaching the goal of having North Korean refugees achieve economic self-sufficiency. In line with this, settlement support for North Korean refugees shifted focus to self-sustainability, thereby underlining the importance of employment support and social adaptation education (MOU 2010). As the number of North Korean defectors entering South Korea sharply increased beginning in the mid-200os, a social integration point of view of North Korean refugees becoming a part of South Korean society and partners to prepare for unification became far more pronounced.

From the point of view of social integration, the settlement support policy has become a broader part of South Korea's unification policy to help North Korean refugees overcome social exclusion and differences in values and the ways of life in South Korean society while adjusting to the South's different political and economic systems (Krechel 1999; Kwon 2014). Given that unification of the Korean peninsula is a process, this institutional base of social integration is expected to lead to system integration between different parts of the social system or its institutions (Mouzelis 1997; Marshall 1998; Sul et al. 2014). In this regard, Lee's successor, President Park Geun-hye, described North Korean defectors as "the harbingers of unification" and "a test-bed for unification" (Yonhap News 2016). Beyond the humanitarian responsibility of a state to protect vulnerable people, North Korean defectors' adjustment in South Korea became more important for policymakers to manage social and economic integration and to prepare for unification.

\section{CHALLENGES IN SETTLEMENT SUPPORT FOR NORTH KOREANS IN SOUTH KOREA}

The number of North Korean refugees who have entered South Korea reached 30,212 as of December 2016 (MOU 2017). Apart from an arduous journey to cross the border to enter South Korea, North Korean refugees face severe challenges when they go through the resettlement process in South Korea. When North Korean refugees try to adjust their lives in South Korea and dream of lives of middle-class status, they soon realize that the reality is not what they had expected or hoped for. 
Figure 1. Satisfaction with Life in South Korea

(N: 138, Unit: \%)

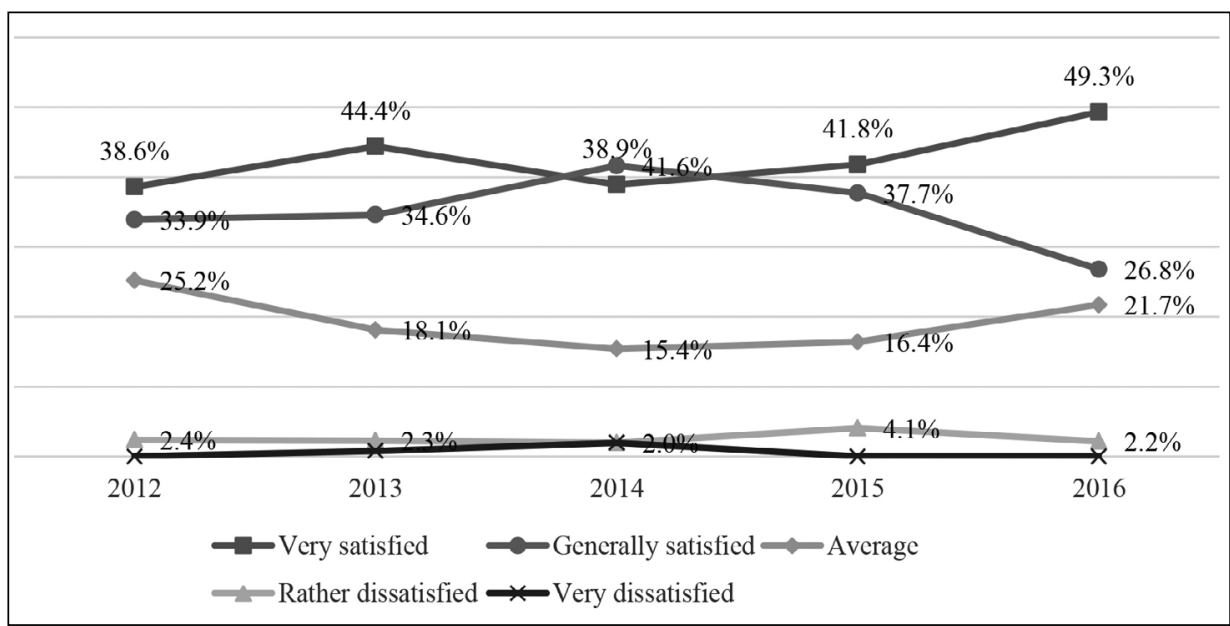

Source: 2016 Unification Attitude Survey of North Korean Refugees, IPUS.

When North Korean refugees come to South Korea, not only are they granted South Korean citizenship by obtaining a resident registration number, but they also receive settlement support from the South Korean government. Hanawon institutionally plays an important role in providing settlement services for North Korean refugees during this initial period. As a part of initial resettlement support, resettlement subsidies are provided to North Korean refugees based on household size. A single adult receives KRW 20 million (about \$17,939), of which about KRW 13 million $(\$ 11,659)$ is for a down payment on a permanent apartment. Moreover, the government provides other financial incentives to encourage social and job-seeking activities. Considering that the provision of housing and other related subsidies are considered significant and of great value to North Korean refugees, South Korea's financial contributions have been highly selective and related to political concerns. Despite generous government support, North Koreans living in South Korea encounter many difficulties, and many of them feel loneliness and isolation.

Recent survey data on North Korean refugees living in South Korea may provide a clue as to how North Korean refugees settle down in South Korea and what the actual conditions and difficulties they face adjusting to South Korean society. According to the 2016 Unification Attitude Survey of North Korean 
Refugees $^{5}$ (IPUS 2017a), 76.1 percent of respondents stated that they were satisfied with life in South Korea (Very satisfied: $49.3 \%$ + Generally satisfied: 26.8\%) (Figure 1).

Survey data from the Korea Hana Foundation ${ }^{6}$ (KHF) also indicated that 67 percent of respondents stated they were satisfied with life in South Korea (KHF 2017). Despite the different samplings between the two surveys, both results showed that two-thirds of North Korean refugees were generally satisfied with life in South Korea.

The KHF (2017) survey showed that, as to the reasons for being dissatisfied with life in South Korea, 'Economic difficulty' was the primary reason for their dissatisfaction, scoring 58 percent. 'Prejudice and discrimination against North Korean refugees' was the second most popular reason at 31.7 percent, and 'A serious gap between what I am capable of and what I want to do' made up the rest at 25.3 percent (Figure 2).

Considering that the most recent motivations that led refugees to flee North Korea were either economic or environmental, economic adaptation has become a critical factor in North Korean refugees' determination of satisfaction with life in South Korea. In fact, the economic activities of North Korean refugees were very vulnerable during the initial stage, and female North Koreans particularly experienced difficulties in securing jobs and stable incomes (IPUS 2017a). The rate of economic activity should be expected to increase the longer they stay in South Korea, experiencing more employment opportunities. According to a survey by KHF (2017), the rate of employment and economic activity of North Korean defectors living in South Korea recorded 55 and 57.9 percent, respectively, in 2016. However, it should noted that the pattern of employment in South Korea is in part due to the government subsidy program that pays half of all wages for North Korean refugee employees. Moreover, the present employment assistance is unlikely to be sustainable in case of a large influx of North Korean refugees (Kim 2016). Considering that economic adaptation through employment is key to determining their level of satisfaction and acculturative stress, the government needs comprehensive plans to improve the economic conditions of North Korean refugees for social adaption and integration into South Korean society (Kim and Kim 2016; Jung et al. 2013).

\footnotetext{
${ }^{5}$ IPUS's survey especially targets North Korean refugees who have entered South Korea within the past year. The total of valid respondents was 128 in 2012, 133 in 2013, 149 in 2014, 146 in 2015, and 138 in 2016.

${ }^{6}$ This survey was conducted on North Korean refugees aged 15 or older among those who entered South Korea from 1997 to 2015. By 2016, 11,914 refugees had completed the survey.
} 
Figure 2. Reasons for Being Dissatisfied with Life in South Korea

(N: 414, Unit: \%)

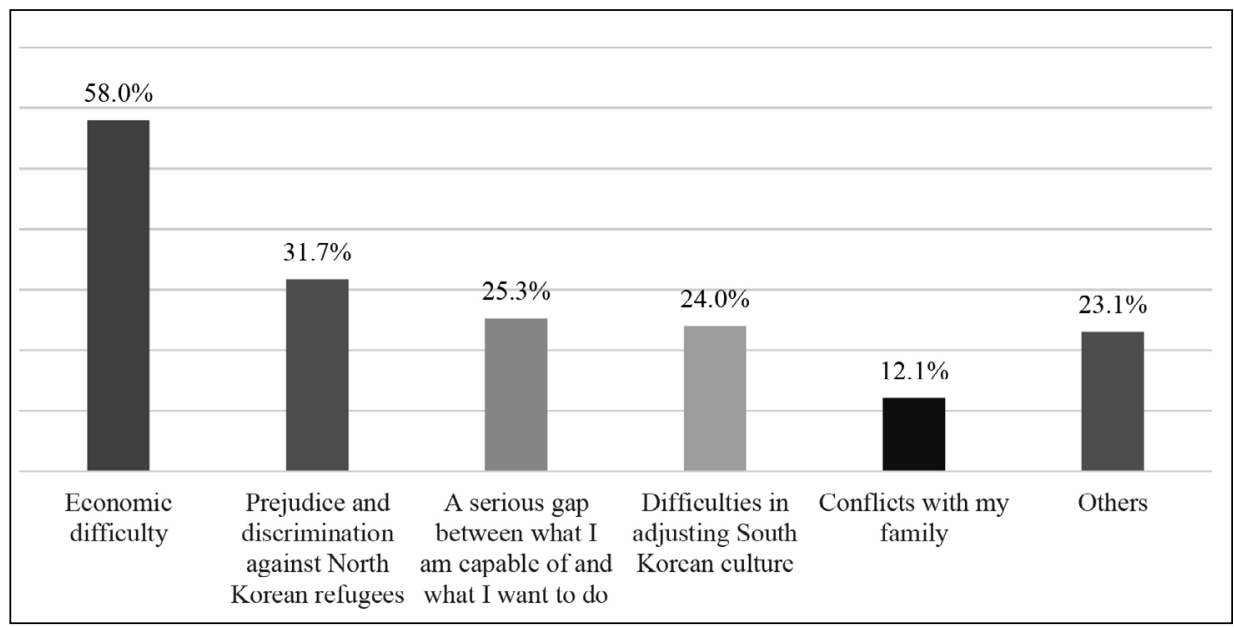

Note: Multiple responses allowed.

Source: 2016 Settlement Condition Survey of North Korean Refugees in South Korea, KHF.

It is also noteworthy that North Korean refugees experience bias and discrimination that decrease their level of satisfaction with their current lives in South Korea. At the individual level, the nature of the coexistence of North and South Korean people is to experience cooperative/conflictive relationships in their daily lives. If their subjective feelings or judgments of being not treated equally continue, the social, psychological, and cultural adjustment of North Korean refugees that South Korea's resettlement policy aims to achieve will be far more difficult. Economic and socio-cultural factors should not be ignored in the process of promoting the adaptation of North Korean refugees.

The challenge is also attributed to attitudinal changes among the South Korean public toward North Korean refugees. With regard to the government's support policies, South Korean attitudes are becoming more negative towards the expansion of aid to North Korean refugees and to the accommodation all North Korean refugees in South Korea (IPUS 2017b). This suggests that South Koreans are in doubt about the state's selective contributions to assisting North Korean refugees. Accepting all North Korean refugees as citizens is a legal obligation for South Korea, and integrating them into South Korean society is the essential foundation for South Korea's refugee policy. Notwithstanding, the way in which 
South Korea responds to North Korean refugees is significantly influenced by domestic constraints stemming from both North and South Koreans. Irrespective of individual choice or rights, North Korean refugees who have settled down in South Korea continue to search for new opportunities in a third country. ${ }^{7}$ Considering that the state is a key actor in refugee affairs, the South Korean government should reinforce capabilities to respond to new challenges that will emerge from a changing domestic environment and an internationally recognized refugee condition.

\section{CONCLUSION}

The ways of identifying and dealing with North Koreans in South Korea have been influenced by a political environment constructed by international and domestic politics and inter-Korean relations. The political discourse, policy choices, and practices related to North Korean refugees have been strongly associated with these structural and institutional conditions.

In the context of South Korean politics, there have been discernible changes in the attitudes towards and awareness of North Korean refugees. Having different political interests and objectives, nearly every modern South Korean administration regularly has revised the law and policies pertaining to the status of North Korean refugees and the margin of support they have received. Change also has been driven by elite perceptions of North Korean refugees and North Korean regime, evaluations of policy effectiveness, strategic policy goals, and reflections on the humanitarian and global norms surrounding the refugees. Despite governmental resettlement policies and social welfare support, North Korean refugees have gone through hardships both known and hidden in South Korea. While survey results show that they generally have been satisfied with life in South Korea, they also have experienced difficulties in adapting to different economic circumstances and newfound political independence.

The problem of North Korean refugees has to do not only with how well they do, but also how South Koreans recognize them. The evolution of terminology to describe those who flee North Korea exemplified the incomplete consensus and discord surrounding various related issues in South Korean society. The changing judgment as to how to recognize, define, and accept North Koreans who have been perceived as heroes, brethren, escapees, and settlers continues

\footnotetext{
${ }^{7}$ Available at http://www.koreatimes.co.kr/www/nation/2017/11/103_23886o.html (accessed on November 14, 2017).
} 
to have a decisive influence on the political agenda and mode of interactions between North Korean refugees and South Korean society.

Considering that the modern view of refugees is that they are those who were under a 'well-founded fear of persecution' or conditions of immediate or long-term threat to their survival, many of the North Korean refugees, who are economic or environmental migrants, may not well fit this category. The system of states caused the refugee phenomenon in Korea. The act of crossing borders continues under the division structure of the Korean peninsula, the dire human rights situation in North Korea, and the diverse motivations of North Koreans in search of a better life. This reality creates political and humanitarian responsibilities for South Korea to protect North Korean refugees during their migration and to create a better environment for their resettlement and adjustment in South Korean society.

\section{REFERENCES}

Barnett, Michael. 2014. "Refugees and Humanitarianism.” In Elena FiddianQasmiyeh, Gil Loescher, Katy Long, and Nando Sigona eds., The Oxford Handbook of Refugee and Forced Migration Studies. Oxford: Oxford University Press, 241-252.

Betts, Alexander and Gill Loescher. 2011. Refugees in International Relations. Oxford: Oxford University Press.

Cha, Victor D. 2012. The Impossible State: North Korea, Past and Future. London: Bodley Head.

Choi, Sheena. 2011. "Ethnic Brethren and National 'Other': North Korean Refugee Youths in South Korea.” Oxford Monitor of Forced Migration 1(2), 51-57.

Chun, Doo-hwan. 1984. Collections of Selected Speeches of President Chun Doo Hwan Vol. IV. [In Korean] Seoul: Office of the President.

Chung, Byung-Ho. 2009. "Between Defector and Migrant: Identities and Strategies of North Koreans in South Korea.” Korean Studies 32, 1-27. . 2004. "Illusion and Maladaptation of the North Korean Refugees: The Influence of the Confusions in Perception by the South Korean Society.” Cross-Cultural Studies [In Korean] 10(1), 33-62.

Cohen, Roberta. 2014. "China's Forced Repatriation of North Korean Refugees Incurs United Nations Censure.” International Journal of Korean Studies 18(1), 59-90. . 2010. "Legal Grounds for Protection of North Korean Refugees." Life 
\& Human Rights 57(1), 9-14.

Eberstadt, Nicholas. 2007. The North Korean Economy: Between Crisis and Catastrophe. New Brunswick, NJ: Transaction Publishers.

Goodwin-Gill, Guy S. 2014. "The International Law of Refugee Protection.” In Elena Fiddian-Qasmiyeh, Gil Loescher, Katy Long, and Nando Sigona eds., The Oxford Handbook of Refugee and Forced Migration Studies. Oxford: Oxford University Press, 36-47.

Haddad, Emma. 2008. The Refugee in International Society: Between Sovereigns. Cambridge: Cambridge University Press.

Heller, Brittan. 2011. "Terms of Endangerment: Evolving Political and Legal Terminology for North Koreans." Oxford Monitor of Forced Migration $1(1), 14-19$.

IPUS (Institute for Peace and Unification Studies). 2017a. 2016 Unification Attitude Survey of North Korean Refugees. [In Korean] Seoul: Institute for Peace and Unification Studies.

. 2017b. 2016 Unification Attitude Survey. [In Korean] Seoul: Institute for Peace and Unification Studies.

Jung, Jin-Hwa, Sohn, Sang-Hee, and Lee, Ju-Kwan. 2013. "Education and Training of Female North Korean Refugees." International Journal of Korean Unification Studies [In Korean] 22(1), 267-296.

Jung, Kwangho, Kim Minyoung, and Kum Hyunsub. 2010. "Problem Definition and the Change of North Korean Defector Resettlement Policy." Korean Policy Studies Review [In Korean] 19(1), 71-101.

Kim, Byung-Yeon. 2016. "Was the First Representation of Unification Successful?” JoongAng Daily [In Korean] (October 19). Accessed at http://news.joins.com/article/20749315 (May 25, 2017).

Kim, Dae-jung. 2004a. The 21st Century and the Korean People - Selected Speeches of Kim Dae-jung, 1998-2004. Seoul: Hakgojae.

Kim, Dong-choon. 2000. War and Society: What Was the Korean War to Us? Seoul: Tolbegae.

Kim, Hyo-jin. 2017. "North Korean Defectors Choosing Third Countries over South Korea." The Korean Times (November 6).

Kim, Jyung-Soo and Kim Joon-Ho. 2016. "The Relationship between Social Support and Acculturative Stress from Cultural Adaptation of People Displaced from North Korea to South Korea." China Journal of Social Work 9(1), 3-24.

Kim, Philo. 1994. An Analysis of the Background on the Emerging of North Korean Defectors. [In Korean] Seoul: Korea Institute for National Unification. 
Kim, Samuel S. 2004b. Inter-Korean Relations: Problems and Prospects. New York: Palgrave Macmillan.

Kim, Sung Kyung. 2012. "'Defector,' 'Refugee,' or 'Migrant'? North Korean Settlers in South Korea's Changing Social Discourse." North Korean Review 8(2), 94-110.

Ko, Sung Ho, Chung Kiseon, and Oh Yoo-seok. 2004. "North Korean Defectors: Their Life and Well-being After Defection." Asian Perspective 28(2), 65-99.

Koo, Bon Ho and Jo Dongho. 1995. "Comparative Analysis of the North and South Korean Economies." In Cho, Lee-Jay and Kim Yoon Hyung eds., Economic Systems in South and North Korea: The Adgenda for Economic Integration. Seoul: Korea Development Institute, 21-55.

KHF (Korea Hana Foundation). 2017. "2016 Settlement Condition Survey of North Korean Refugees in South Korea.” [In Korean] Seoul: Korea Hana Foundation.

KINU (Korea Institute for National Unification). 2005. White Paper on Human Rights in North Korea 2005. Seoul: Korea Institute for National Unification.

Kreckel, Reinhard. 1999. "Social Integration, National Identity and German Unification.” In J.T. Marcus ed., Surviving the Twentieth Century: Social Pilosophy from the Frankfurt School to Columbia Faculty Seminars. New Brunswick: Transaction Publishers, 85-95.

Kwon, Sook Do. 2014. "A Study on South Korean Social Integration Policy for North Korean Defactors.” Journal of Korean Politics [In Korean] 23(1), 101-126.

Lankov, Andrei. 2004. "North Korean Refugees in Northeast China." Asian Survey 44(6), 856-873.

Lee, Keum-Soon. 1999. A Solution of the Issue of North Korean Defectors. [In Korean] Seoul: Korea Institute for National Unification. 1999.

Lee, Kyu-Chang, Kim Soo-Am, Cho Jung-Hyun, and Yoo Hyun-Jung. 2012. International Treaties and Laws on North Korean Defectors. [In Korean] Seoul: Korea Institute for National Unification.

Lee, Sookja. 2009. "Korean Government's Policy on North Korean Defectors in China: With the Emphasis on the Administration of Kim Dae-jung and Roh Moo-hyun." The Korean Journal of International Studies [In Korean] 49(5), 251-271.

Loescher, Gill. 2001. The UNHCR and World Politics: A Perilous Path. Oxford: Oxford University Press.

Maley, William. 2016. What is a Refugee? London: Hurst \& Co.. 
Marchall, Gordon. 1994. The Concise Oxford Dictionalry of Sociology. Oxford: Oxford University Press.

Memorandum of Conversation. 1969. Foreign Relations of the United States, 1969-1976, Volume XIX, Part 1, Korea, 1969-1972, Document 35. [Online]. Nixon Presidential Materials, NSC Files, Box 1023, Presidential/HAK MemCons, Washington: Department of State. Accessed at http://history.state.gov/historicaldocuments/frus196976v19p1/d35 (May 16, 2012).

MOU (Ministry of Unification). 2001. 2001 White Paper on Korean Unification. Seoul: Ministry of Unification. 2010. 2010 White Paper on Korean Unification. Seoul: Ministry of Unification. 2017. 2017 White Paper on Korean Unification. [In Korean] Seoul: Ministry of Unification.

Moon, Chung-in. 2000. "The Sunshine Policy and the Korean Summit: Assessments and Prospects." East Asian Review 12(4), 3-36.

Mouzelis, Nicos. 1997. "Social and System Integration: Lockwood, Habermas, Giddens." Sociology 31(1), 111-119.

Park, Hyun Sun. 2002. "Prospects and Development for Resettlement Support Policy for North Korean Defectors." North Korean Studies Review [In Korean] 6(1), 209-240.

Park, Myoung-kyu, Kim Philo, Kim Soo-Am, Song Young Hoon, and Yang UnChul. 2011. North Korean Diaspora: Global Migration and Settlement of North Koreans. [In Korean] Seoul: Institute for Peace and Unification Studies.

Park, Seo Yeon. 2016. "Street-level Bureaucracy and Depoliticized North Korean Subjectivity in the Service Provision of Hana Center." Asian Ethnicity 17(2), 199-213.

Shen, Zhihua and Yafeng Xia. 2014. "Chinese-North Korean Relations and Chinese Policy Toward Korean Cross-Border Migration, 1950-1962.” Cold War Studies 16(4), 133-158. . 2013. "Contested Border: A Historical Investigation into the SinoKorean Border Issue, 1950-1964." Asian Perspective 37(1), 1-30.

Smith, Hazel. 2005. "North Korea in China: Fact from Fiction." In Akaha, Tsuneo and Anna Vassilieva eds., Crossing National Borders: Human Migration Issues in Northeast Asia. Tokyo: United Nations University Press, 165-190.

Son, Sarah A. 2016. "Identity, Security and the Nation: Understanding the South Korean Response to North Korean Defectors." Asian Ethnicity 
17(2), 171-184.

Song, Young Hoon. 2016. "Conceptual Configuration of North Korean Human Rights: North Koreans Abroad as Citizen, Refugee, or Migrant.” The Journal of Multicultural Society [In Korean] 9(2), 69-94.

Song, Jiyoung. 2015. "Twenty Years' Evolution of North Korean Migration, 1994-2014: A Human Security Perspective." Asia \& the Pacific Policy Studies 2(2), 399-415.

Sul, Jin Bae, Song Eun-Hee, and Lee Eun-Mi. 2014. "Social Integration of North Korean Refugees in South Korea: The Effects of Economic Adaptation on Psychological Adaptation." Journal of Northeast Asian Studies 70, 157-174.

UNHCR (The Office of the United Nations High Commissioner for Refugees). 2016. "Global Trends: Forced Displacement in 2016, Annex Table2." Accessed at http://www.unhcr.org/globaltrends2016/ (May 28, 2017). . 2010. "Convention and Protocal Relating to the Status of Refugees." Accessed at http://www.unhcr.org/protection/basic/3b66c2aa1o/ convention-protocol-relating-status-refugees.html (June 3, 2017).

Won, Jae Chun. 2003. A New Phase of North Korean Refugees Issues: Problems and Solutions. [In Korean] Seoul: Korea Institute For Martime Strategy.

Yang, Un-Chul. 2008. "Structural Change of Market and Political Slack in North Korea." In Paik, Haksoon and Cheong Seong-Chang eds., North Korea in Distress: Confronting Domestic and External Challenges. Seongnam: The Sejong Institute, 61-93.

Yeon, Ha-Cheong. 1986. The Economic Policy and Operation in North Korea. [In Korean] Seoul: Korea Development Institute.

Yonhap News. 2016. "President Park, North Korean Defectors, the First Representation of Unification." [in Korean] (October 11). Accessed at http://www.yonhapnews. co.kr/bulletin/2016/10/11/0200000000AKR20161011108100001. HTML?from=search (October 14, 2016).

Yoon, In-Jin. 2001. "North Korean Diaspora: North Korean Defectors Abroad and in South Korea." Development and Society 30(1), 1-26.

Yoon, Yeo Sang. 2003. "A Policy Proposal of the Sudden Increase in the Number of North Korean Defectors." National Strategy [In Korean] 9(1), 65-88.

[Received Sep 27, 2017; Revised Nov 15, 2017; Accepted Dec 5, 2017] 